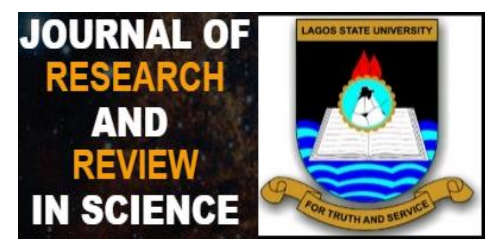

\title{
Heavy Metal Concentrations in Chrysichthys nigrodigitatus (Lacepede, 1803) and Eichhornia crassipes (Mart) from Ologe Lagoon and its Tributaries in Lagos, Nigeria
}

\author{
*Prince Emeka NDIMELE' , Gabriel Olarinde MEKULEYI ${ }^{1}$, Emmanuel Fatai AUDU ${ }^{1}$, Oluseyi Olaide LAWAL ${ }^{1}$ and \\ Joshua NWEZE'
}

Department of Fisheries, Faculty of Science, Lagos State University, Ojo, Lagos State, Nigeria

\section{${ }^{*}$ Correspondence}

Prince Emeka NDIMELE

E-mail: drpendimele@yahoo.com;

emeka.ndimele@lasu.edu.ng

Telephone:+2348038205109

$+2348094277377$

\begin{abstract}
:
Introduction: Heavy metal content of aquatic ecosystems is attracting global attention because of the ecological and human health risks associated with high levels of these metals in the environment.

Aim: This study investigated the heavy metal content of various compartments of Ologe Lagoon in order to ascertain the safety of the consumption of fish and other resources from this water body.

Materials and Methods: Samples were collected between June and November 2015, from the stations on monthly basis. Some physicochemical parameters (alkalinity, salinity, $\mathrm{pH}$, turbidity and hardness) and the levels of five heavy metals ( $\mathrm{Zn}, \mathrm{Fe}, \mathrm{Cu}, \mathrm{Cd}$ and $\mathrm{Pb}$ ) in water, sediment, Eichhornia crassipes and a commercially important fish (Chrysichthys nigrodigitatus) were studied using standard procedures.

Results: The ranges of values of the metals in sediment were: $\mathrm{Fe}$ $\left(431.10 \pm 109.75-2560.33 \pm 1101.32 \mathrm{mgkg}^{-1}\right), \mathrm{Zn} \quad(3.77 \pm 2.55-17.29 \pm 5.30$ $\left.\mathrm{mgkg}^{-1}\right), \mathrm{Cu}\left(7.45 \pm 6.55-35.21 \pm 33.79 \mathrm{mgkg}^{-1}\right), \mathrm{Pb}(5.98 \pm 2.29-12.89 \pm 4.22$ $\left.\mathrm{mgkg}^{-1}\right)$ and $\mathrm{Cd}\left(0.31 \pm 0.31-0.88 \pm 0.21 \mathrm{mgkg}^{-1}\right)$. The concentrations of heavy metals (except $\mathrm{Cu}$ ) in Eichhornia crassipes exceeded FEPA and WHO maximum permissible limits $\left(\mathrm{Zn}=0.6 \mathrm{mgkg}^{-1} ; \mathrm{Cu}=10.0 \mathrm{mgkg}^{-1} ; \mathrm{Pb}\right.$ $=2.0 \mathrm{mgkg}^{-1} ; \mathrm{Cd}=0.02 \mathrm{mgkg}^{-1}$ ). The mean concentrations of heavy metals (except $\mathrm{Zn}$ ) in Chrysichthys nigrodigitatus were above the limit recommended by FEPA and WHO.

Conclusion: The study showed that the metal load in the biota of Ologe Lagoon is increasing, and this may be harmful to inhabitants of the community, who depend on the services provided by this aquatic ecosystem. Therefore, efforts should be made by all users of the water bodies especially the industries to treat their wastes before discharging them into these aquatic ecosystems.
\end{abstract}

Keywords: Chrysichthys nigrodigitatus, Eichhornia crassipes, heavy metals, ecosystem, health. 


\section{INTRODUCTION}

Aquatic ecosystems are affected by numerous health stressors that significantly deplete biodiversity. Future predicted loss of biodiversity and its effects are greater for aquatic ecosystems in comparison with terrestrial ecosystems [1]. The increase in pollution of aquatic environments could be attributed to increasing industrial development, urbanization and inadequate consideration for environmental impact among other factors. The indiscriminate release of wastes of organic and inorganic nature changes physico-chemical characteristics of water and causes hazard to flora and fauna of the aquatic. Heavy metals are the most important forms of aquatic pollutants and may accumulate in the tissues of fish, which are often at the top of the aquatic food chain [2]. The progressive and irreversible accumulation of metals in various tissues of aquatic creatures ultimately leads to metal-related diseases in the long run because of its toxic nature, thereby endangering the aquatic biota and other organisms [3]. Chrysichthys nigrodigitatus is an economically valuable fish species with excellent flesh quality and palatability. These qualities embedded in $C$. nigrodigitatus made it a favourite for consumption in Nigeria especially by Lagosians. However, most of the fingerlings and adult of this species consumed by Nigerians are sourced from Lagoon - a habitat often susceptible to both domestic and industrial wastes [4]. Therefore, the objective of this study was to determine the health status of Ologe Lagoon and its tributaries (Agbara, Era, Imude, Morogbo and Under-bridge) with regards to the level of heavy metals in water column, sediment, Eichhornia crassipes and a commercially important fish - Chrysichthys nigrodigitatus.

\section{MATERIALS AND METHODS}

\subsection{Study Area}

Ologe Lagoon (Fig.1) has a surface area of about 64.5 $\mathrm{km}^{2}$ and it lies between latitude $6^{\circ} 27^{\prime} \mathrm{N}$ and $6^{\circ} 30^{\prime} \mathrm{N}$ and longitudes $3^{\circ} 02^{\prime} \mathrm{E}$ and $3^{\circ} 07^{\prime} \mathrm{E}$ on the equator [5]. It links up to Atlantic Oceans via Badagry Creek and the Lagos harbour. It has an average depth of $2.42 \mathrm{~m}$ and an average temperature of $30^{\circ} \mathrm{C}$ during sunny days [6]. Ologe Lagoon is located in Oto-Awori in Ojo local Government Area, Lagos State, Nigeria and the indigenous inhabitants are the Aworis and Towo-Owo, a nearby town that has a river called River Owo, which is the major source of water to Ologe Lagoon [6]. The Lagoon is bounded in the north by Igbesa and Agbara in Ogun state, and ljanikin town in Lagos state. It shares boundaries in the south with Gbanko and Badagry Creek across villages such as Idoluwo, Egan, Ojota, Igede and Ojo town.

\subsection{Collection of Samples and Pre-treatment}

Samples of water, sediment, Eichhornia crassipes and Chrysichthys nigrodigitatus were collected from six sampling stations; Otto Jetty, Agbara, Imude, Era,
Morogbo and Under-bridge of Otto, for six months between June and November, 2015. The study period comprises of 3 months each of wet season (June August) and dry season (September November). Three (3) sampling points were chosen at each sampling station. Water was collected $20 \mathrm{~cm}$ below the water surface from each sampling point once each month by using acid-clean $1.5 \mathrm{~L}$ polycarbonate bottles. From each water sample collected, $100 \mathrm{~mL}$ was measured and acidified with $0.5 \mathrm{~mL}$ of nitric acid to prevent microbial degradation of the metals present. Water sample was refrigerated at $-4^{\circ} \mathrm{C}$ before laboratory analysis. Physicochemical water parameters such as temperature, $\mathrm{pH}$, alkalinity, salinity, total hardness and turbidity were measured. Water temperature and $\mathrm{pH}$ were measured in situ using probe meter (Hanna portable $\mathrm{pH} / \mathrm{EC} / \mathrm{TDS} /$ temperature meter, HI 98129 model) while water turbidity was measured using nephelometer (Analite portable nephelometer Model 156, Mcvan Instrument, Mulgrave). Alkalinity and salinity were determined using titrimetric method while total hardness was measured using spectrophotometer.

Fish, sediment and plant samples were collected and transported in polyethylene bags, previously cleaned and treated with $5 \%$ nitric acid and rinsed with distilled water [7]. The fish and plant samples were washed with tap water and stored in a freezer at $-4^{\circ} \mathrm{C}$ for 96 hours.

\subsection{Sample Treatment and Metal Analysis}

All frozen samples were defrosted at room temperature $\left(25^{\circ} \mathrm{C}\right.$ attained in 5-6 hours). Water samples were shaken thoroughly and then heavy metal $\mathrm{Zn}, \mathrm{Fe}, \mathrm{Cu}$, $\mathrm{Cd}$ and $\mathrm{Pb}$ ) concentrations in water samples were determined using Buck Scientific Atomic Absorption Spectrophotometer (VGP 210 model, USA). Sediment samples were dried with hotplate for $10 \mathrm{~min}$ and thereafter allowed to cool and sieved with $0.5 \mathrm{~mm}$ sieve in preparation for digestion and heavy metal analysis. Metal content of the digested sediment samples was determined using atomic absorption spectrophotometer (Buck scientific 210VGP model). 20 Samples of whole fresh fish and plant were selected from each station, weighed and oven-dried at $105^{\circ} \mathrm{C}$ for 28 hours till a constant weight was obtained. Dried samples were grounded into powdery form (with ceramic mortar and pestle) and $2 \mathrm{~g}$ of each sample was digested according to APHA [7] method. Heavy metal contents were determined with atomic absorption spectrophotometer (Buck scientific 210/211 VGP model). The concentration $\left(\mathrm{mg} \mathrm{kg}^{-1}\right)$ of the metals was calculated, with reference to Peer and Rosen [8].

\subsection{Statistical Analyses}

Data were expressed as mean \pm standard deviation. The monthly and spatial variations of the metals in the samples were tested by one-way analysis of variance (ANOVA) and Duncan multiple range test was used to separate the means when the difference is significant. In addition, the seasonal variations were determined by 
t-test. The level of significance was set at $p<0.05$ and all statistical analyses were carried out with statistical package for social sciences (SPSS windows version 17.0, Chicago, USA).

\section{RESULTS}

\subsection{Physico-Chemical Parameters and Heavy Metals of Water Samples}

The spatial variation of the water samples at each station was presented in Table I. The highest value of $\mathrm{pH}$ was recorded in Otto Jetty $(6.59 \pm 0.38)$ and the lowest in Under-bridge (5.56 \pm 0.64$)$. Similarly, Otto Jetty had the highest value of alkalinity $(40.00 \pm 5.29 \mathrm{mg} / \mathrm{L})$ and Agbara the lowest $(29.50 \pm 3.40 \mathrm{mg} / \mathrm{L})$. The highest hardness value was obtained in Era $(4766.67 \pm 4610.95$ $\mathrm{mg} / \mathrm{L})$ and lowest in Imude $(60.67 \pm 9.96 \mathrm{mg} / \mathrm{L})$. The peak value for turbidity (30.25 \pm 13.41 NTU) was recorded in Agbara and the lowest $(14.25 \pm 3.04 \mathrm{NTU})$ in underbridge. Salinity concentration $(0.02 \pm 0.00 \mathrm{ppt})$ was highest in Agbara and Morogbo. However, there were significant differences $(p<0.05)$ only in hardness, turbidity and alkalinity across the six sampling stations.

On the contrary, only hardness and turbidity showed significant $(p<0.05)$ seasonal variation in water column during the study (Fig. 2). Hardness value of $1353.17 \pm 1150.55 \mathrm{mg} / \mathrm{l}$ was recorded in wet season while $112.00 \pm 26.89 \mathrm{mg} / \mathrm{l}$ was obtained during dry season. The turbidity values in wet and dry seasons are $24.75 \pm 5.51 \mathrm{NTU}$ and $19.56 \pm 1.28 \mathrm{NTU}$ respectively. The wet and dry season values of the other physicochemical parameters are: $\mathrm{pH}(5.76 \pm 0.35,6.16 \pm 0.19)$, alkalinity $(34.33 \pm 1.70 \mathrm{mg} / \mathrm{l}, 33.11 \pm 2.38 \mathrm{mg} / \mathrm{l})$ and salinity $(0.03 \pm 0.02 p p t, 0.02 \pm 0.03 p p t)$. There was no significant difference $(p>0.05)$ in the spatial and seasonal distribution of heavy metals in the water column.

\subsection{Heavy metal content of sediment}

The concentration of heavy metals in sediment during the dry and wet seasons, and the spatial distribution of metals in the sediment are shown in Figure 3 and Table II respectively. The highest value of iron $\left(2288.27 \pm 329.69 \mathrm{mgkg}^{-1}\right)$ and zinc $\left(23.461 \pm 1.47 \mathrm{mgkg}^{-}\right.$ 1) were obtained during dry season while the peak of $\mathrm{Cu}$ $\left(28.15 \pm 11.09 \mathrm{mgkg}^{-1}\right), \mathrm{Pb}\left(9.79 \pm 1.66 \mathrm{mgkg}^{-1}\right)$ and $\mathrm{Cd}$ $\left(0.76 \pm 0.14 \mathrm{mgkg}^{-1}\right)$ were detected in wet season. All the metals (except $\mathrm{Pb}$ and $\mathrm{Cd}$ ) measured in the sediment had significant $(p<0.05)$ seasonal variation. In term of spatial distribution of metals in the sediment, highest values of $\mathrm{Fe}\left(2560.33 \pm 1101.32 \mathrm{mgkg}^{-1}\right), \quad \mathrm{Cu}$ $\left(35.21 \pm 33.79 \mathrm{mgkg}^{-1}\right), \mathrm{Pb}\left(12.89 \pm 4.22 \mathrm{mgkg}^{-1}\right)$ and $\mathrm{Cd}$ $\left(0.88 \pm 0.21 \mathrm{mgkg}^{-1}\right)$ were obtained from Under-bridge, while $\mathrm{Zn}\left(17.29 \pm 5.30 \mathrm{mgkg}^{-1}\right)$ was highest in Imude. The least values of $\mathrm{Fe}\left(431.10 \pm 109.75 \mathrm{mgkg}^{-1}\right), \mathrm{Zn}$ $\left(3.77 \pm 2.55 \mathrm{mgkg}^{-1}\right)$ and $\mathrm{Cd}\left(0.31 \pm 0.31 \mathrm{mgkg}^{-1}\right)$ were recorded in Era while the least values of $\mathrm{Pb}$ $\left(5.98 \pm 2.29 \mathrm{mgkg}^{-1}\right)$ was obtained in Otto Jetty and $\mathrm{Cu}\left(7.45 \pm 6.55 \mathrm{mgkg}^{-1}\right)$ in Morogbo. All the metals (except Cd) in the sediment had spatial significant difference $(p<0.05)$ across the sampling stations (Table II).

\subsection{Heavy metal content of water hyacinth}

The seasonal and spatial variations of heavy metals in the plant species (Eichhornia crassipes) from the six sampling stations are shown in Figure 4 and Table III respectively. All the metals (except $\mathrm{Cd}$ ) showed significant $(p<0.05)$ seasonal and spatial variation. The values of the metals during wet and dry season respectively are: $\mathrm{Fe} \quad\left(139.71 \pm 13.26 \mathrm{mgkg}^{-1}\right.$, $\left.618.25 \pm 236.42 \mathrm{mgkg}^{-1}\right), \mathrm{Zn}\left(129.77 \pm 51.13 \mathrm{mgkg}^{-1}\right.$, $\left.87.14 \pm 36.23 \mathrm{mgkg}^{-1}\right), \mathrm{Cu}\left(9.97 \pm 3.79 \mathrm{mgkg}^{-1}, 0.47 \pm 0.09\right.$ $\left.\mathrm{mgkg}^{-1}\right), \mathrm{Pb}\left(18.60 \pm 2.89 \mathrm{mgkg}^{-1}, 7.54 \pm 1.24 \mathrm{mgkg}^{-1}\right)$ and $\mathrm{Cd}\left(1.51 \pm 0.30 \mathrm{mgkg}^{-1}, 0.60 \pm 0.16 \mathrm{mgkg}^{-1}\right)$.

\section{Heavy metal content of silver catfish (Chrysichthys nigrodigitatus) from the Sampling Stations}

The seasonal variation of heavy metals in fish is shown in Figure 5. Fe, $\mathrm{Zn}$ and $\mathrm{Cu}$ were significantly $(\mathrm{p}<0.05)$ affected by the difference in season while $\mathrm{Pb}$ and $\mathrm{Cd}$ showed no significant $(p>0.05)$ seasonal variation. The value of heavy metals in wet and dry seasons respectively are $\mathrm{Fe}\left(9.29 \pm 9.292 \mathrm{mgkg}^{-1}\right.$;

$\left.22.19 \pm 7.13 \mathrm{mgkg}^{-1}\right), \mathrm{Zn}\left(0.75 \pm 0.75 \quad \mathrm{mgkg}^{-1}\right.$ $\left.25.35 \pm 16.27 \mathrm{mgkg}^{-1}\right), \quad \mathrm{Cu}\left(13.56 \pm 13.56 \mathrm{mgkg}^{-1}\right.$; $\left.0.15 \pm 0.13 \mathrm{mgkg}^{-1}\right), \mathrm{Pb}\left(2.20 \pm 2.20 \mathrm{mgkg}^{-1} ; 1.71 \pm 0.07\right.$ $\left.\mathrm{mgkg}^{-1}\right)$ and $\mathrm{Cd}\left(0.15 \pm 0.14 \mathrm{mgkg}^{-1} ; 0.19 \pm 0.10 \mathrm{mgkg}^{-}\right.$ 1 ). However, there was no spatial variation of heavy metal in Chrysichthys nigrodigitatus during this study.

\section{DISCUSSION}

\section{Physico-chemical Parameters and Heavy Metals in Water Column}

The $\mathrm{pH}$ value obtained in this study is ideal for fish growth and survival [9]. Similar value of $\mathrm{pH}$ has been reported in Iko River [10] and in Asejire Lake [11]. Dissolved oxygen and $\mathrm{pH}$ concentrations of water bodies are important parameters that determine the spatial and temporal distribution of aquatic organisms, particularly the fish fauna [12]. The $\mathrm{pH}$ values in this study are within the recommended permissible limit of $6.5-8.5$ [13]. The highest turbidity value $(24.75 \pm 5.51$ NTU) recorded in the wet season exceeded that of FEPA considerable limits for fresh water body [14]. Turbidity is associated with suspended solid concentrations. Therefore, the high turbidity content obtained in this study could be attributed to waste inputs from industries. Also, the high turbidity recorded in Agbara sampling station agrees with earlier findings [15], which reported that water body closest to industrial area have high turbidity. The highest total hardness value obtained in the wet season in this study is considered too high for fresh water or lagoon [9]. Thus, Ologe Lagoon can be considered as hard water using the standard given by [16] where waters with total hardness higher than $40 \mathrm{mg} / \mathrm{l}$ are considered hard. The high values of alkalinity in the wet and dry seasons obtained in Ologe Lagoon suggest that the lagoon sediment or floor contain high level of carbonated 
deposits [9]. The metal concentrations in water samples of all the sampling stations were below the recommended permissible limits. However, the values of heavy metals in water sample during this study were higher than those reported in River Pompom in Okehi Local Government Area of Kogi [17] but lower than those obtained in El-Mex Bay, Alexandria, Egypt [18] and in India [19].

\section{Heavy metals in Sediment, plant and Fish species}

All the metals (except Fe) in the sediment samples did not exceed WHO maximum permissible limit [20]. The presence of $\mathrm{Fe}, \mathrm{Zn}, \mathrm{Pb}, \mathrm{Cu}, \mathrm{Cd}$ in sediments, plant (Eichhornia crassipes) and fish (Chrysichthys nigrodigitatus) samples indicated the exposure of the water bodies and its aquatic resources to pollution whose sources could be point or non-point. This is in agreement with the report of [21] that rapid industrialization, coupled with technological advances in agriculture, has introduced various pollutants (synthetic and organic) into the aquatic ecosystems. The ranges of heavy metals in sediment in this study are higher than those reported in Badagry Creek [22] and in Bangladesh [23]. High concentration of heavy metals in $E$. crassipes could be attributed to the indiscriminate dumping of industrial and domestic wastes into surrounding water bodies [24, 25]. The concentrations of heavy metals (except $\mathrm{Cu}$ ) in $E$. crassipes exceeded FEPA and WHO maximum permissible limits [26]. The relatively high concentration of iron in the sediment, fish and E. crassipes samples may be attributed to the fact that iron is an essential micronutrient associated with many proteins and enzymes [27]. The observed low concentrations of $\mathrm{Cd}$ and $\mathrm{Cu}$ in the $E$. crassipes could be due to the efficient mechanism of elimination by this plant. Sources of cadmium include plastic products from household wastes, burning of tyres and rubber products, rock minerals from which the soil is formed, ores of zinc, copper and lead as well as from industrial wastes. Cd and $\mathrm{Pb}$ are known for their high toxicity [28]. Cadmium has no known physiological role in aquatic organisms and is considered as one of the most toxic metals in the aquatic environment [29]. All the values of heavy metals recorded in sediment and $E$. crassipes in this study are lower than those reported in Saudi Arabia [30] and in Epe Lagoon [31].

The mean concentrations of heavy metals (except Zn) in Chrysichthys nigrodigitatus in the present study are above the limit recommended by FEPA and WHO [26]. The Fe content of $C$. nigrodigitatus in this study is higher than the value reported in Pseudotolithus elongatus [32]. Iron is an essential component of haemoglobin, which is responsible for oxygen transportation in the body. The $\mathrm{Cu}$ content in $C$. nigrodigitatus recorded in this study is higher than the values reported in previous studies such as in $C$. nigrodigitatus $[29,33]$ but lower than that reported in Parachanna obscura [31] from Epe Lagoon. The $\mathrm{Zn}, \mathrm{Pb}$ and $\mathrm{Cd}$ values in fish in this study are above those found in Oreochromis niloticus [11] and in Pseudotolithus elongatus [32]. On the contrary, $\mathrm{Pb}$ and $\mathrm{Cd}$ contents recorded in $C$. nigrodigitatus in the present study is lower than the valus recorded in Scomber scombrus [34,35]. The results of this study is comparable to earlier reports on fish samples from Anambra River [36], Calabar River [37] and Izmir bay in Turkey [38]. The fact that the fish species studied is one of the most preferred and heavily consumed species in human diet in the study area indicates the extent of risk to which the people could be exposed as regard metal poisoning through the continuous consumption of this species of fish.

\section{CONCLUSION}

This study has shown the presence of heavy metals $(\mathrm{Zn}, \mathrm{Fe}, \mathrm{Cu}, \mathrm{Cd}$ and $\mathrm{Pb})$ in water, sediment, Eichhornia crassipes and fish (Chrysichthys nigrodigitatus). Concentrations of $\mathrm{Fe}$ in the sediment; $\mathrm{Fe}, \mathrm{Pb}, \mathrm{Zn}$ and $\mathrm{Cd}$ in Eichhornia crassipes and $\mathrm{Fe}, \mathrm{Pb}, \mathrm{Cu}$ and $\mathrm{Cd}$ in Chrysichthys nigrodigitatus were above the limit recommended by FEPA and WHO. The study showed that water quality variables of Ologe Lagoon and its tributaries can still sustain fish but the metal load in their biota is increasing and this may be harmful to inhabitants of the communities who depend on the services provided by these aquatic ecosystems.

\section{ACKNOWLEDGEMENTS}

The authors acknowledge the invaluable inputs of anonymous reviewers whose contributions gave rise to this paper.

\section{COMPETING INTERESTS}

We declare that there are no competing interests

\section{AUTHORS' CONTRIBUTIONS}

Prince Emeka NDIMELE, Gabriel Olarinde MEKULEYI and Joshua NWEZE designed the study. Emmanuel Fatai AUDU, Joshua NWEZE and Oluseyi Olaide LAWAL performed the statistical analysis, managed the literature searches and wrote the first draft of the manuscript. Prince Emeka NDIMELE, Gabriel Olarinde MEKULEYI and Joshua NWEZE reviewed the first draft before submission. 


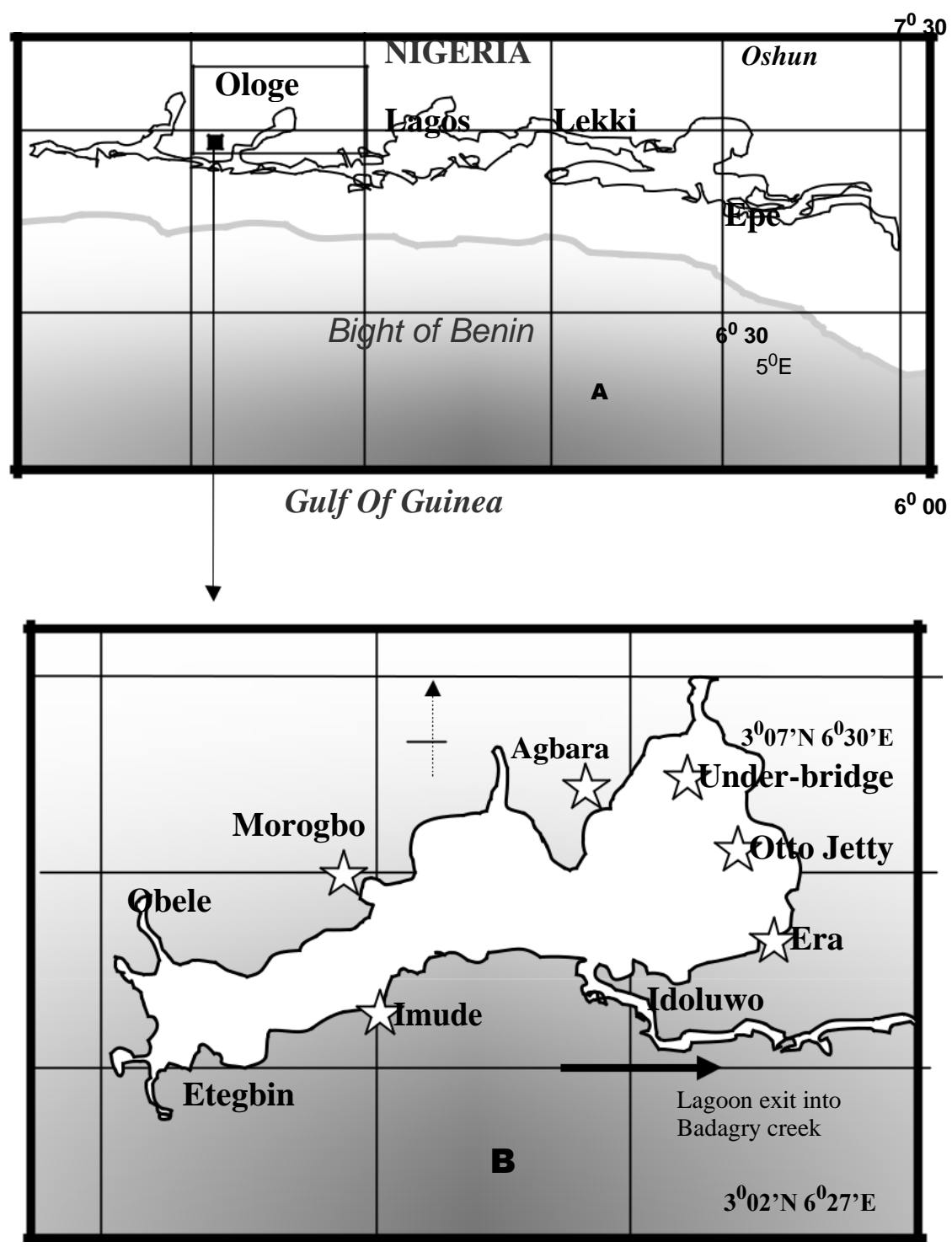

Figure 1: Location of study sites - (A) Map of Lagos Lagoon complex - inset: Ologe Lagoon; and (b) Map of Ologe Lagoon. Sampling stations are marked with stars (Scale: 1:150,000).

Table I: Spatial Variation in Physico-Chemical Parameters of Water Samples from the Sites

\begin{tabular}{llllll}
\hline Stations & $\mathbf{p H}$ & $\begin{array}{l}\text { Alkalinity } \\
(\mathbf{m g} / \mathbf{l})\end{array}$ & $\begin{array}{c}\text { Salinity } \\
(\mathbf{p p t})\end{array}$ & $\begin{array}{l}\text { Hardness } \\
(\mathbf{m g} / \mathbf{l})\end{array}$ & $\begin{array}{l}\text { Turbidity } \\
(\mathbf{N T U})\end{array}$ \\
\hline Agbara & $5.81 \pm 0.30^{\mathrm{a}}$ & $29.50 \pm 3.40^{\mathrm{a}}$ & $0.02 \pm 0.00^{\mathrm{a}}$ & $250.00 \pm 121.65^{\mathrm{a}}$ & $30.25 \pm 13.41^{\mathrm{a}}$ \\
Otto Jetty & $6.59 \pm 0.38^{\mathrm{a}}$ & $40.00 \pm 5.29^{\mathrm{ab}}$ & $0.01 \pm 0.00^{\mathrm{a}}$ & $106.67 \pm 52.68^{\mathrm{ab}}$ & $16.67 \pm 1.86^{\mathrm{ab}}$ \\
Imude & $5.69 \pm 1.04^{\mathrm{a}}$ & $34.67 \pm 1.76^{\mathrm{b}}$ & $0.01 \pm 0.00^{\mathrm{a}}$ & $60.67 \pm 9.96^{\mathrm{b}}$ & $29.67 \pm 3.07^{\mathrm{b}}$ \\
Morogbo & $5.66 \pm 0.39^{\mathrm{a}}$ & $33.50 \pm 2.50^{\mathrm{b}}$ & $0.02 \pm 0.00^{\mathrm{a}}$ & $264.00 \pm 164.66^{\mathrm{bc}}$ & $19.75 \pm 12.73^{\mathrm{b}}$ \\
Era & $6.56 \pm 0.32^{\mathrm{a}}$ & $30.00 \pm 1.16^{\mathrm{bc}}$ & $0.01 \pm 0.00^{\mathrm{a}}$ & $4766.67 \pm 4610.95^{\mathrm{c}}$ & $25.67 \pm 3.18^{\mathrm{bc}}$ \\
Underbridge & $5.56 \pm 0.64^{\mathrm{a}}$ & $36.00 \pm 3.37^{\mathrm{c}}$ & $0.01 \pm 0.00^{\mathrm{a}}$ & $97.00 \pm 33.84^{\mathrm{cd}}$ & $14.25 \pm 3.04^{\mathrm{bd}}$ \\
\hline
\end{tabular}

Values with same superscript in the column are not significantly $(p>0.05)$ different. All the values are expressed as Mean \pm SD. 


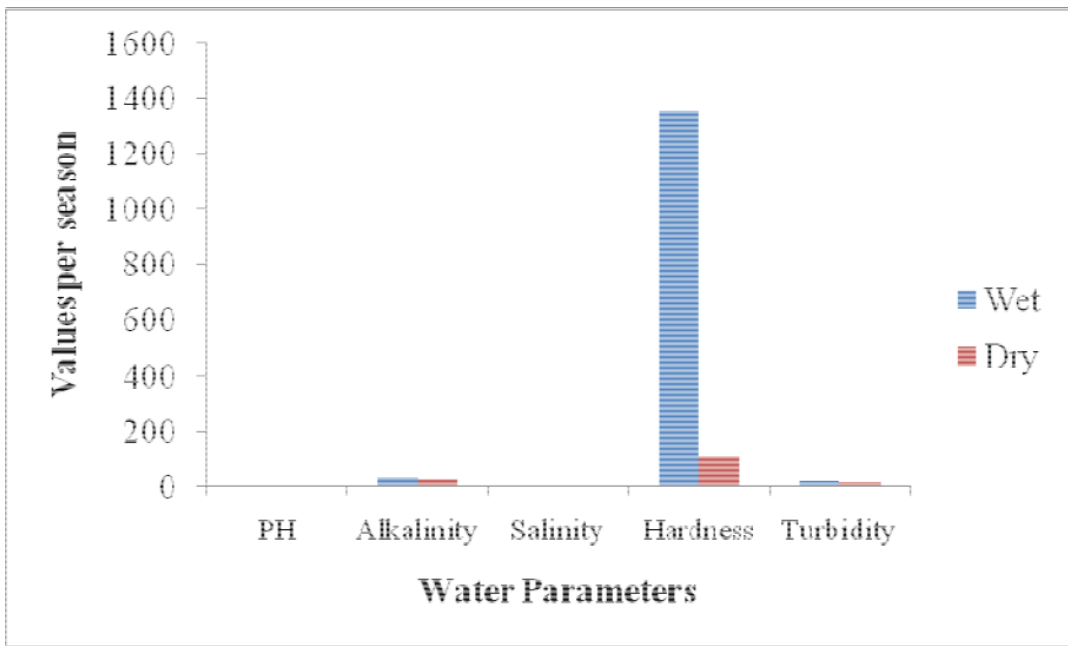

Figure 2: Seasonal Variation of Physico-Chemical Parameters of Water Samples from the Sites

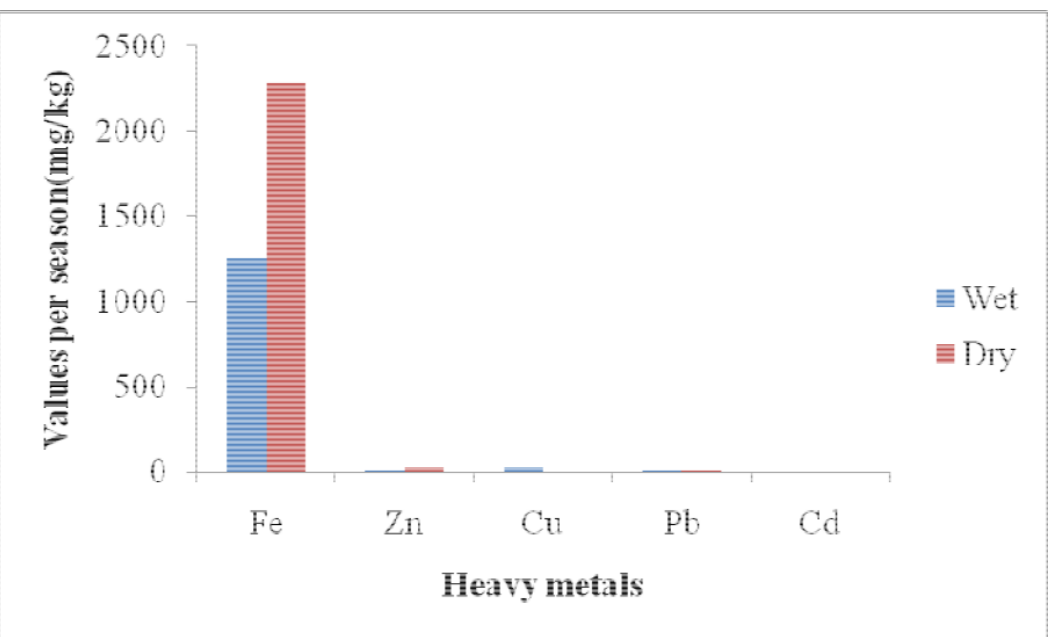

Figure 3: Seasonal Variation of Heavy Metals in Sediment

Table II: Spatial Variation of Heavy Metals in Sediment

\begin{tabular}{llllll}
\hline Stations & $\begin{array}{l}\text { Fe } \\
(\mathbf{m g} / \mathbf{k g})\end{array}$ & $\begin{array}{l}\mathbf{Z n} \\
(\mathbf{m g} / \mathbf{k g})\end{array}$ & $\begin{array}{l}\mathbf{C u} \\
(\mathbf{m g} / \mathbf{k g})\end{array}$ & $\begin{array}{l}\mathbf{P b} \\
(\mathbf{m g} / \mathbf{k g})\end{array}$ & $\begin{array}{l}\mathbf{C d} \\
(\mathbf{m g} / \mathbf{k g})\end{array}$ \\
\hline Agbara & $1739.63 \pm 823.79^{\mathrm{a}}$ & $13.08 \pm 5.29^{\mathrm{a}}$ & $12.68 \pm 11.34^{\mathrm{a}}$ & $7.05 \pm 1.18^{\mathrm{a}}$ & $0.66 \pm 0.23^{\mathrm{a}}$ \\
Otto Jetty & $1833.81 \pm 456.59^{\mathrm{b}}$ & $15.01 \pm 5.71^{\mathrm{b}}$ & $14.94 \pm 14.42^{\mathrm{b}}$ & $5.98 \pm 2.29^{\mathrm{b}}$ & $0.34 \pm 0.17^{\mathrm{a}}$ \\
& & & & & \\
Imude & $1874.24 \pm 595.47^{\mathrm{ab}}$ & $17.29 \pm 5.30^{\mathrm{ab}}$ & $9.99 \pm 7.68^{\mathrm{ab}}$ & $11.79 \pm 2.68^{\mathrm{bc}}$ & $0.54 \pm 0.31^{\mathrm{a}}$ \\
Morogbo & $1157.18 \pm 419.43^{\mathrm{bc}}$ & $13.73 \pm 4.89^{\mathrm{bc}}$ & $7.45 \pm 6.55^{\mathrm{ac}}$ & $8.82 \pm 3.98^{\mathrm{c}}$ & $0.74 \pm 0.29^{\mathrm{a}}$ \\
Era & $431.10 \pm 109.75^{\mathrm{c}}$ & $3.77 \pm 2.55^{\mathrm{c}}$ & $17.50 \pm 16.15^{\mathrm{c}}$ & $7.65 \pm 1.98^{\mathrm{c}}$ & $0.31 \pm 0.11^{\mathrm{a}}$ \\
Under-bridge & $2560.33 \pm 1101.32^{\mathrm{cd}}$ & $16.48 \pm 5.83^{\mathrm{cd}}$ & $35.21 \pm 33.79^{\mathrm{cd}}$ & $12.89 \pm 4.22^{\mathrm{cd}}$ & $0.88 \pm 0.21^{\mathrm{a}}$ \\
WHO & 40 & 123 & 25 & 30 & 0.5 \\
\hline
\end{tabular}

Values in the same column and with the same superscript letters are not significantly ( $p>0.05)$ different. All the values are expressed as Mean $\pm S D$. 
Table III: Spatial Variation of Heavy Metals in Plant (Eichhornia crassipes) from the Sampling Stations

\begin{tabular}{|l|l|l|l|l|c|}
\hline Stations & $\mathbf{F e}$ & $\mathbf{Z n}$ & $\mathbf{C u}$ & $\mathbf{P b}$ & $\mathbf{C d}$ \\
\hline Agbara & $378.01 \pm 280.68^{\mathrm{a}}$ & $156.05 \pm 86.17^{\mathrm{a}}$ & $5.32 \pm 4.60^{\mathrm{a}}$ & $10.32 \pm 4.89^{\mathrm{a}}$ & $0.77 \pm 0.37^{\mathrm{a}}$ \\
\hline Otto Jetty & $954.84 \pm 658.07^{\mathrm{b}}$ & $75.52 \pm 64.57^{\mathrm{b}}$ & $0.44 \pm 0.23^{\mathrm{b}}$ & $4.04 \pm 2.14^{\mathrm{b}}$ & $0.24 \pm 0.24^{\mathrm{a}}$ \\
\hline Imude & $91.53 \pm 37.26^{\mathrm{c}}$ & $82.67 \pm 45.48^{\mathrm{b}}$ & $3.47 \pm 3.32^{\mathrm{a}}$ & $9.29 \pm 5.68^{\mathrm{a}}$ & $0.85 \pm 0.57^{\mathrm{a}}$ \\
\hline Morogbo & $247.97 \pm 164.26^{\mathrm{d}}$ & $15.41 \pm 6.65^{\mathrm{c}}$ & $0.77 \pm 0.34^{\mathrm{b}}$ & $8.45 \pm 3.39^{\mathrm{a}}$ & $0.58 \pm 0.37^{\mathrm{a}}$ \\
\hline Era & $64.98 \pm 64.98^{\mathrm{c}}$ & $11.08 \pm 11.08^{\mathrm{c}}$ & $1.04 \pm 1.04^{\mathrm{b}}$ & $6.94 \pm 6.94^{\mathrm{ab}}$ & $0.50 \pm 0.50^{\mathrm{a}}$ \\
\hline Under-bridge & $134.50 \pm 48.22^{\mathrm{e}}$ & $74.43 \pm 55.83^{\mathrm{b}}$ & $5.59 \pm 5.38^{\mathrm{a}}$ & $10.29 \pm 5.68^{\mathrm{a}}$ & $1.00 \pm 0.45^{\mathrm{a}}$ \\
\hline WHO & - & 0.6 & 10.0 & 2.0 & 0.02 \\
\hline
\end{tabular}

Values in the same column and with the same superscript letters are not significant $(p>0.05)$ different. All the values are expressed as Mean $\pm S D$.

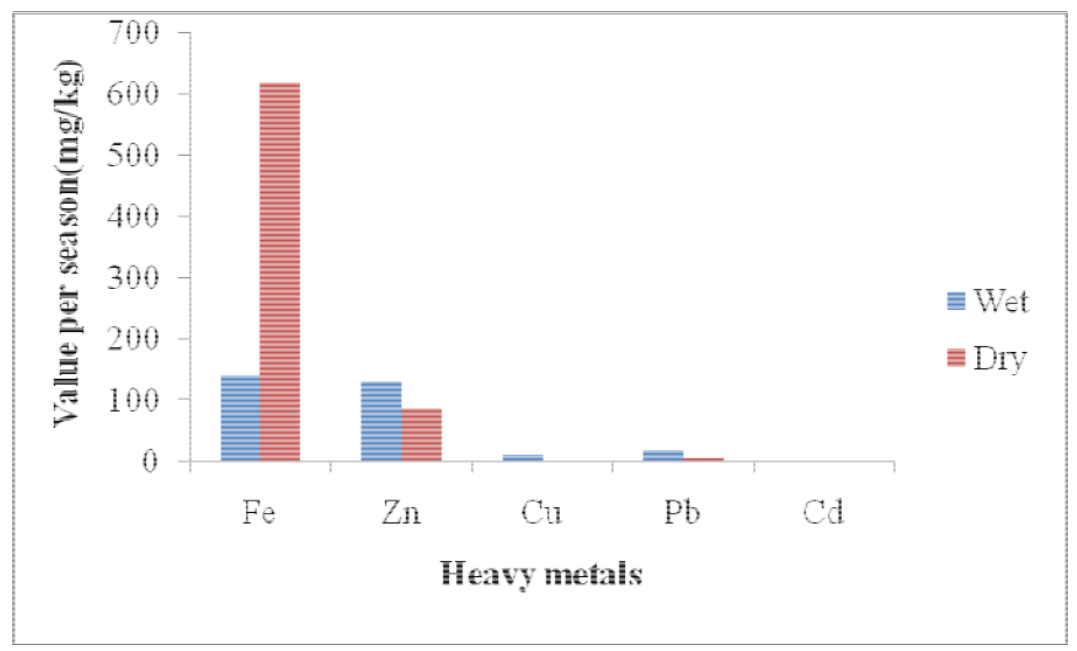

Figure 4: Seasonal Variation of Heavy Metals in Plant (Eichhornia crassipes) from the Sampling Stations

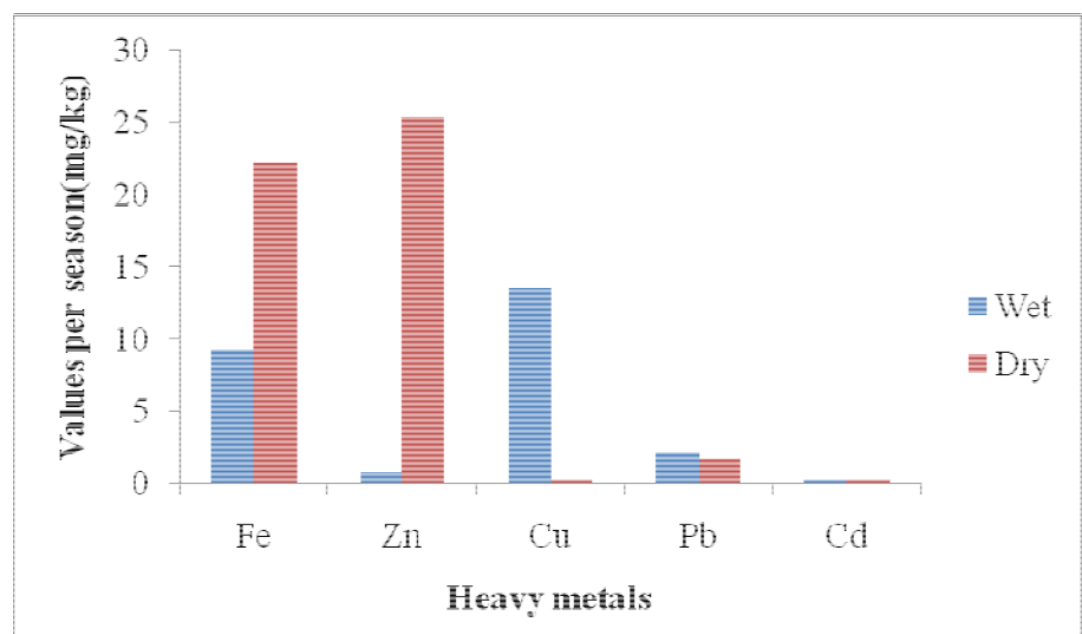

Figure 5: Seasonal Variation of Heavy Metals in Fish (Chrysichthys nigrodigitatus) from the Sampling Stations 


\section{REFERENCES}

1. Sala, O. E., Chapin, F. S., Armesto, J. J., Berlow, E., Bloomfield, J., Dirzo, R., HuberSanwald, E., Huenneke, L. F., Jackson, R. B., Kinzig, A., Leemans, R., Lodge, D. M., Mooney, H. A., Oesterheld, M., Poff, N. L., Sykes, M. T., Walker, B. H., Walker, M. and Wall, D. H. (2000). Global biodiversity scenarios for the year 2100. Science 287: 1770-1774.

2. Dirican, S., Çilek, S., Çiftçi, H., Bıyıko ğlu, M.,

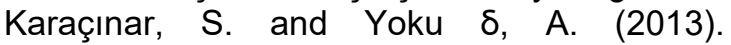
Preliminary study on heavy metal concentrations of Anatolian Khramulya, Capoeta tinca (Heckel, 1843) from Çamlıgöze Dam Lake, Sivas, Turk ey. Journal of Environmental Health Science and Engineering 11 (7): 1-6.

3. Mallampati, S. R., Bhavesh, M., Sunil, D., Manish, J., Leena, K., Venkatrama, K. S. S., Shaik, B., Gadde, R. and Prashant, B. (2007). Bioaccumulation of heavy metals in some commercial fishes and crabs of the Gulf of Cambay, India. Current Science Journal 92 (11): 1489-1491.

4. Whenu, O.O. and Mekuleyi, G.O.(2017).Bioaccumulation of Heavy Metals in the Tissues of African Snakehead (Parachanna obscura) from Epe Lagoon, Lagos, Nigeria. International Journal of Current Science and Studies 1(1):1-4.

5. Kumolu-Johnson, C.A., Ndimele, P.E., Akintola, S.L. and Jibuike, C.C. (2010). Copper, zinc and iron concentrations in water, sediment and Cynothriss amento (Regan 1917) from Ologe Lagoon, Lagos, Nigeria: A preliminary survey. African Journal of Aquatic Science, 35: 87-94.

6. Ndimele, P.E., Akintola, S.L. and Jibuike, C.C. (2010). Copper, zinc and iron concentrations in water, sediment and Cynothrissa mento (Regan 1917) from Ologe Lagoon, Lagos, Nigeria: A preliminary survey. Africa Journal of Aquatic Science.35: 87-94.

7. APHA,(2005). Standard Methods for the Examination of Water and Wastewater, 21st edition American Public Health Association. Washington DC, $1368 \mathrm{p}$.

8. Peer, J. R. and Rosen, W. G. (1977). Lead and cadmium content of urban garden vegetables.
Trace Substances and Environmental Health 11: $399-405$.

9. Boyd, C.E., (1981).Water quality in warm water fish ponds. Alabama Agricultural Experimental Station, Auburn University, Alabama, 358p.

10. Usoro, E., Enewan, U. and Thomas, H. (2013): Seasonal Variation of Physicochemical Parameters of Water and Sediments from Iko River, Nigeria. 3: 103.

11. Jenyo-Oni, A. and Oladele, A.H. (2016). Heavy metals assessment in water, sediments and selected aquatic organisms in Lake Asejire, Nigeria. European Science Journal, 12(24), 339-351.

12. Araoye, P.A. (2009). The seasonal variation of $\mathrm{pH}$ and dissolved oxygen (DO) concentration in Asa lake llorin, Nigeria, International Journal of Physical Sciences 4(5): 271-274.

13. World Health Organization (WHO), (1985). Recommended limit for metals in fin fish. Environmental health, Criteria Principles for safety and assignment of food additive and contamination in food. Technical report series 505, Geneva, p309.

14. FEPA (Federal Environmental Protection Agency (2007). Guidelines and Standards for Environmental Pollution Control in Nigeria.

15. Ugwu, A.I., Wakawa, R.J., La'ah, E. and Olotu, A. (2012). Spatial distribution of heavy metals in river Usuma sediments and study of factors impacting the concentration. IJRRAS, 12(2): 294-303.

16. Kendrick, M. J., May, J., Plishka, M. J. and Robinson, K. D. (1992). Metals in biological systems. Ellis Horwood Ltd, England.

17. Matthews, A., Omono, C. and Kakulu, S.(2012). Physico-chemical parameters and heavy metals in River Pompom in Okehi Local Government Area of Kogi State, Nigeria. International Research Journal of Biotechnology 3(8): 134-140.

18. Khaled, A. (2004). Heavy metal concentrations in certain tissues of five commercially important fish species from El-Mex Bay, Alexandria, Egypt. Egyptian Journal of Aquatic Biology and Fisheries, 8(1):51-64. 
19. Tepe, Y. (2014). Toxic Metals: Trace Metals C hromium, Nickel, Copper, and Aluminum, In Encyclopedia of Food Safety, edited by Yasmine Motarjemi,, Academic Press, Waltham, Pages 356-362.

20. World Health Organisation (2010). Food standard program on contaminants in food, $4^{\text {th }}$ session, World Health Organisation, 35.

21. Ogbeibu, A. E. and Ezeunara, P. U. (2002). Impact of brewery effluents on the Ikpoba River, using the fish communities as bio-indicators. Journal of Aquatic Resources 17: 35-44.

22. Ndimele, P.E. and Kumolu-Johnson, C.A.(2012).Some Aspects of the Physicochemistry and Heavy Metal Content of Water, Sediment and Cynothrissa mento (Regan, 1917) from Badagry Creek, Lagos, Nigeria. Trends in Applied Sciences Research,7: 724- 736.

23. Sarker, J M.D., Kanungo, I, Tanmay, M.H. and Patwary, S.A. (2016) A Study on the Determination of Heavy Metals in Sediment of Fish Farms in Bangladesh. Fisheries and Aquaculture Journal 7:150-159.

24. Ntekim, E.E., Ekwere, S.J. and Ukpong, E.E. (1993). Heavy metal distribution in sediments from Calabar River, South East of Nigeria. Journal of Environment and Geology 21: 237241.

25. Asuquo, F., Ogri, R. and Bassey, E. (1999). Distribution of heavy metals and total hydrocarbons in coastal waters and sediments of Cross River, South Eastern Nigeria.

26. WHO (1996). Permissible limits of heavy metals in soil and plants (Geneva: World Health Organization), Switzerland.

27. Gil, S.M., Gubala, M. A., Landers, C., Lasorsa, D. H., Crescelium, B. E. and Curtis, L. R. (1997). Heavy metals accumulation in sediment and fresh water fish in U.S Arctic Lakes. Environmental Toxicology and Chemistry 16: 733- 741.

28. Oladimeji (1986). The Bioaccumulation of Heavy Metals in Fish in Kaduna River. Journal of Chemical Society of Nigeria 27 (2): 173-176.

29. Obasohan, E.E.J., Oronsaye A.O. and Obano, E.E. (2006). Heavy metal concentration in Malapteruruselectricus and Chrysichthys nigrodigitatus from Ogba in Benin City, Nigeria. African Journal of Biotechnology, 5: 974-982.

30. Mortuza, M.G. and Al-Misned, F.A. (2017).Environmental Contamination and Assessment of Heavy Metals in Water, Sediments and Shrimp of Red Sea Coast of Jizan, Saudi Arabia. Journal of Aquatic Pollution and Toxicology 1:1-23.

31. Whenu, O.O. and Mekuleyi, G.O. (2017). Bioaccumulation of Heavy Metals in the Tissues of African Snakehead (Parachanna obscura) from Epe Lagoon, Lagos, Nigeria. International Journal of Current Science and Studies 1(1):1-4.

32. Mekuleyi, G.O. and Joseph, O.O. (2017). Levels of Heavy Metals in Pseudotolithus elongatus from Badagry Market, Nigeria. Turkish Journal of Aquatic Sciences 32(4): 184188.

33. Edet, O.A., Udoudo, M.E., Ekam, I.A. and Ngozi, O.A. (2014). Levels of heavy metals in fish obtained from two fishing sites in Akwa Ibom State, Nigeria. African Journal of Environmental Science and Technology, 8(7), 416- 421.

34. Abubakar, A., Uzairu, A., Ekwumemgbo, P.A. and Okunola, O.J. (2014). Evaluation of heavy metals concentration in imported frozen fish (Trachurus murphyi) sold in Zaria market, Nigeria. American Journal of Chemistry, 4(5), 137-154.

35. Kareem, O.K., Orisasona, O. and Olanrewaju, N. (2016). Determination of heavy metal levels in some commonly consumed frozen fish in Ibadan, southwest, Nigeria. Research Journal of Environmental Toxicology, 10 (1): 82-87.

36. Obodo, G.A. (2004). The Bioaccumulation of Heavy Metals in Fish from Anambra River. Journal of Chemical Society of Nigeria 1: 15-17.

37. Nwaedozie, J.M. (1998). Heavy metal distribution in sediment in Calabar River, South Eastern Nigeria. Journal of Environment and Geology 21: 37- 40.

38. Kucuksezgin, F. A., Kontas, O. Altay, E., and Uluturhan, E.D. (2006). Assessment of marine pollution in Izmir Bay; Nutrient heavy metal and total hydrocarbon concentrations: Environmental International 32 
